\title{
Haemophilus parainfluenzae, Penicillinase Positive
}

National Cancer Institute

\section{Source}

National Cancer Institute. Haemophilus parainfluenzae, Penicillinase Positive. NCI

Thesaurus. Code C123488.

Any bacterial species identified as Haemophilus parainfluenzae that produces the enzyme penicillinase. 